Ю.О.Омельченко,

аспірант відділу філософських

проблем природознавства та екологї

Інституту філософії імені Г.С. Сковороди

НАН України

\title{
ІНЖЕНЕРІЯ «РОЗУМНИХ» РЕЧЕЙ
}

Інженерія XXI ст. займає одне 3 центральних місць праксису людини, а отже, вимагає уваги з боку соціогуманітаріїв. Інженерія, техніка та наука певною мірою розглядалися філософією ХХ ст. як терміни, що не виходили за межі дисципліни «філософія науки і техніки», а поняття «інженерія» та «техніка» не завжди розглядалися окремо та мали суто техніцистське тлумачення. Сучасний філософський дискурс розглядає ці концепти як окремі й самодостатні. Автор дослідження виходить 3 позицій розгляду науки, техніки та інженерії як взаємопов'язаних, але окремих сфер людського духу. Сучасні технічні артефакти мають всеохопний вплив на соціогуманітарну сферу і $є$ продуктами творчості людини - людини-інженера, людини-техніка, людини-науковця. 3 іншого боку, через автономність та аутопоезис технічних артефактів людина достатньою мірою сама стає продуктом власних інженерних творінь. Через революційні наукові, технічні, інженерні прориви, такі, як Mega science, Big Data science, Hi-tech та Hi-hume технологіï, NBICS-революціï тощо, завдяки сучасним соціогуманітарним переосмисленням, інженерія XXI ст. автором дослідження розглядається як один 3 ключових рушіїв поступу й трансформації людини. Дослідження фокусується на розгляді інженерії «розумних» речей (приладів), а саме Інтернету «розумних» речей (скорочено IPP). Дана соціотехнічна система через власну мережеву структуру впливає на культуру, економіку, політику, побут, дозвілля, медицину, гуманітарну сферу, науку, освіту людини.

Філософськими дослідженнями науки, технонауки, технічних наук, техніки та технічних артефактів, технології, інженерії, соціальної інженерії різною мірою займалися такі мислителі: С.Дацюк, В.Лук'янець, М.Савостьянова, В.Ратников, М.Розін, В.Горохов, А. Андреєв, Х.Сколимовскі, О.Шпенглер, М.Гайдеггер, Д.Ріфкін, М.Маклюен, М.Кастельс, Н. Луман, К. Поппер. 
Метою дослідження є експлікація концепту «інженерія» та осмислення процесів і перетворень, які несе людині інженерія XXI ст., а саме - інженерія «розумних» речей. Автор дослідження ставить за мету висвітлити соціально-антропологічне значення концепту «інженерія», проаналізувати роль інженерії «розумних» речей у перетворенні людини, проблему людини, що творить, та людини, яка сама є продуктом власного творення.

Людина з часів первісного ладу займалася створенням засобів, які б сприяли іiї біологічному, а з часів появи культури - й соціальному виживанню. Такими засобами були усна мова, знаряддя праці та полювання, одежа, оселя, групова динаміка (розподілення ролей у соціальних групах), письмо, державні утворення, інститути права, освіта, релігія, філософія, медицина, мистецтво, техніка, наука. Такі засоби вважатимемо медіаторами, тобто посередниками, між людиною та іiі зовнішнім (природа, інші люди, соціальні системи та інститути) і внутрішнім (індивідуальність, особистість) світами. Процеси еволюції медіаторів захистили біологічне виживання сучасної людини від природи - погодні умови, брак їжі та води, хижі тварини наразі не становлять загрози. Виробництво сучасних медіаторів спрямовано, з одного боку, на реалізацію творчих інтенцій людини, іiі жаги до осягання всесвіту, розвитку ефективного господарства, з іншого, - на вгамування апетитів суспільства споживання, а саме - на виробництво низькосортних продуктів мистецтва та медійних продуктів, задоволення гіпертрофованого бажання наслідувати моду в одязі та стилі тощо.

Інженерія - це сукупність процесів творення артефактів культури, як матеріальних, так і нематеріальних. Мається на увазі широке соціально-антропологічне розуміння інженерії, ми відходимо від інструментально-технічного вжитку поняття. Власне інженерія (від лат. ingenium - здібність, винахідливість та лат. ingeniare«вигадувати, розробляти») - це створення, винайдення, виробництво медіаторів та інших артефактів 3 прагматичною метою поліпшення або відновлення якості і продуктивності біологічних, соціальних, культурних, духовних, технічних систем і механізмів. Така практика завжди була когнітивно-перетворювальною, тобто кожен акт такої діяльності є, з одного боку, дослідженням природи, 3 іншого, - iï перетворенням та олюдненням. Втім, не кожен акт творення є інженерією, не кожна діяльність має кінцеву, поставлену людиною, мету. Людина-інженер - це, насамперед, людина-творець 
3 утилітарним ухилом власної діяльності. Щоб уникнути редукції «будь-яка практика $\epsilon$ інженерією», наведемо розмежування.

Філософія до певної межі є видом інженерії - це винайдення, розробка та дизайн смислів, онтологій, гносеологій, етичних та естетичних систем, антропологічних концепцій тощо. Філософія, як інструмент соціальної інженерії, може адмініструвати соціальні системи: етичні розробки впливають на правові інститути, естетичні - на мистецтво, епістемологічні - на науку тощо. Філософія, мистецтво або наука, які не мають прагматичної детермінованої мети, на нашу думку, не входять до поняттєвого поля «інженерії». Представники цих трьох сфер людського духу, які споглядають і досліджують світ, особливо його фундаментальні конструкти, безумовно займаються творчістю й виробляють артефакти культури, але не $\epsilon$ інженерами. Філософ, митець або ж науковець, який не ставить прагматичних цілей, наприклад, вдосконалити конкретні положення логіки або онтології, вгамувати соціальне замовлення конкретного стилю живопису, зробити винахід для поліпшення конкретного механізму, - така людина $\epsilon$ інженером.

Концепт «інженерія» в XXI ст. розрісся в цілу хмару інженерій, серед яких: соціальна інженерія, знаннєва інженерія, будівельна інженерія, інфраструктурна інженерія, автомобільна інженерія, інженерія інформаційних комунікацій, генна інженерія, наноінженерія, інженерія програмного забезпечення, бізнес-інженерія, інженерія економіки та господарства, системна інженерія тощо. Наша увага буде зосереджена на інженерії «розумних» речей. Інженерія XXI ст. це, насамперед, виробництво та розробка такої соціотехнічної системи, як Інтернет «розумних» речей (IPP). IPP, на сьогодні, має контакт з більш як половиною користувачів Інтернету через пошукову систему «гугл» (пошукові системи є «розумними» речами), а до 2020 р. передбачається понад 50 мільярдів «розумних» приладів [1]. Така велика «площа контакту» 3 людиною зумовлює вплив технічного артефакту IPP на цілий спектр діяльності людини.

Інженерія «розумних» речей $є$ складовою соціально-антропологічної інженерії, для якої в добу глобалізації інструменти інженерії «розумних» речей мають вирішальне значення. Інженерія «розумних» речей об'єднує здобутки сучасних інженерій в єдиний наукоємний комплекс, який можна назвати «сумою технологій» XXI ст. Нема сумнівів, що сучасні артефакти техніки мають тенденцію «ставати «розумними». Сучасні прилади, щоб бути ефективними 
та продуктивними, не можуть уникати під’єднання до IPP та «орозумнення». Автомобілі, смартфони, побутова техніка, інфраструктура, смарт-будинки, смарт-міста - все це об'єднується у всесвітню мережу IPP. В XXI ст. тільки окремі деталі чи механізми можуть не бути «розумними», наприклад виделка, дріт, механічний годинник тощо. Але виделка, дріт та механічний годинник будуть надруковані на 3-Д принтері або вироблені робототехнікою на смарт-конвеєрі. Домінування та монополія «розумних» речей зростатимуть, а роль та присутність іншої техніки зменшуватиметься. Більше того, інженерія «розумних» речей стосується створення не тільки технічних артефактів, вона створює нові антропотехнічні середовища існування, «розумні» середовища. Вже сьогодні залежність людини від техніки досягла рівня, коли природа стала непридатною для існування без сучасних технологій. В природному середовищі неможливі сучасні культура, наука мистецтво, освіта, медицина - техносфера стала новою природою-для-людини. «Розумне» середовище задовольняє біологічні, культурні та соціальні потреби краще й ефективніше за природу, але це не означає, що такі середовища будуть позбавлені симуляції природи. Людина зможе 3 допомогою інструментів інженерії XXI ст. симулювати природне середовище, наразі це частково можливо з допомогою аудіоефектів, кліматичної техніки, штучно створених рослин тощо.

У створенні такої потужної соціотехнічної системи, як IPP, використовуються ресурси технонауки та технічних інженерій, соціальної інженерії та економіки. Інженерія «розумних» речей включає такі розробки та технології: нанотехнології, біотехнології, біоніка, smartgrid, BigData, хмарні носії інформації, Інтернет-енергій, Інтернет-логістики, Інтернет-інфраструктури, «розумні» будинки, «розумні міста», «розумний» транспорт, IRIS (Інтернет маршрутизація в космосі), засоби оптичної ідентифікації, дрони тощо.

Інженерія «розумних» речей як когнітивно-перетворювальна практика переробляє та трансформує великі масиви інформації, інфраструктуру, енергію, простір у такі форми, які б задовільняли сучасні потреби людини. Великі масиви інформації отримують нові носіі, наприклад, хмарні. Інфраструктура та логістика стають «розумними» через роботизацію та автономізацію техніки, транспортування стає дешевшим та швидшим. Енергія отримує нову форму носія та споживання - Інтернет-енергій, де ефективність використання та заощадження досягають якісно нових рівнів. Трансформується й 
сам фізичний простір, який стає буквально ближчим для людини. По-перше, IPP покриває всю земну кулю, як через кабельні комунікації, так і через супутники, по-друге, «розумні» речі дають можливість встановлювати зв'язок з позаземною природою: марсоходи, космічні станції і зонди, орбітальні телескопи тощо. Різного виду телескопи надають людині інформацію про об'єкти на відстані тисячі світових років. Фізична мережа «розумних» речей розгортається в просторі сонячної системи, а сенсори «розумних» приладів виходять за іiі межі. Площа контакту IPP зі Всесвітом збільшується.

«Розумні» речі, як і будь-які артефакти техніки, створюються людиною за допомогою ресурсів іiі творчого потенціалу та жаги до досконалості. Втім, інженерний геній сучасної людини доводить техносферу до певної суверенності: «розумні» речі характеризуються аутопоезисом, така техніка доволі автономна та має можливості до самовідтворення. У сучасного інженера техніки між кінцевим його продуктом, наприклад, «розумною» річчю та початком розробки, стоїть ціла низка процесів та циклів, в яких частка участі людини зменшується. Математичні й інженерні обчислення, пошук та обробка даних, інформаційна комунікація, точні виміри, виготовлення деталей та механізмів - все це роблять робототехніка або «розумні» речі. Сучасна людини стає свідком, коли техніка виробляє або навіть відтворює саму себе. В процесі виробництва артефактів техніки IPР крок за кроком перебирає у людини суб'єктність. Наразі від людини ще вимагається натискання кнопки для запуску конвеєра, але чи буде так тривати завжди?

Як ми зазначали вище, інженерія - когнітивно-перетворювальна практика, праксис (перетворення соціальної природи людини) та поезис (дослідження природи, створення та перетворення матеріальних артефактів). Така діяльність має два напрями: перший - це дослідження природи та перетворення іiї у ресурси, другий - це дослідження природи самої людини, здебільшого неорганічного тіла, та перетворення iї у ресурси. В першому випадку людина перетворює корисні копалини або енергію води у матеріали та електричну енергію відповідно. В другому - людина перетворює (вдосконалює) власні артефакти техніки, наприклад, перетворює речі в «розумні» речі. Тут, звичайно, також використовуються ресурси природи, але ключовим залишається перетворення вже створеного. А. Андреєв вбачає ці вияви в практиці технонауки: «3 розвитком технонауки все тісніше пов'язується ідея каталогу «будівельних 
блоків» матеріального світу, з яких, як у відомій дитячій грі «Лего», можна самостійно збирати все нові і нові конструкції (наприклад, в біології це так званий регістр стандартних біологічних елементів). Цілком чітка до цього часу відмінність між природними утвореннями і штучно створеними артефактами абсолютно розмивається. ....все більшої популярності набуває новий, внутрішньо «соціологізований» погляд на техніку як на гетерогенне утворення, в якому переплетені матеріальні, соціальні та «дискурсивні» (тобто логікопонятійні) відносини» [2]. Когнітивно-перетворювальний вектор сучасного інженера зміщується з природи на людину. Інтенція інженера тепер спрямована на природу-для-людини, тобто техносферу, точніше, антропотехносферу. Немає сумнівів, що антропотехносфера є невід'ємною частиною соціотехнічних систем і впливає на цілий спектр перетворень у культурі (наука, освіта, медицина, побут тощо) та фізіології людини (штучні органи, кінцівки тощо). Коли людина перетворює техніку, вона перетворює саму себе. Будь-яка інженерія, особливо така масштабна та наукоємна, як інженерія «розумних» речей, стає інженерією неорганічного, а в деяких випадках - і органічного (тіла людини).

Інженерія природи людини - так можна назвати всі галузі соціальної інженерії XXI ст. Ми виходимо з розуміння інженерії, як втілення ідей в певних видах матеріалу. Такими матеріалами можуть бути біологічні тканини, нежива матерія, соціальні системи, медійний контент, культурний контент, мова, смисли та поняття, знання та освіта, наука і техніка, врешті-решт сама людина. Спираючись на ці міркування, ми пропонуємо розглядати інженерію IPP, яка $є$ частиною соціальної інженерії, інженерією природи людини.

Інженерію «розумних» речей (соціальну інженерію) можна назвати антропотехнікою, тобто сукупністю прикладних гуманітарнотехнічних знань для роботи з людиною з метою ії конструктивного перетворення [3]. Ставлення людини до сучасної техніки описує німецький філософ Солтердайк: «Термін «антропотехніка» вказує на той факт, що майбутнє розпочатого щодо давно процесу доместикації людей людьми залишається відкритим. По-перше, цей термін описує значною мірою несвідоме відпадання людей від чистого тваринного зародку, внаслідок чого вони стали не лише членами «символічного виду», «ритуальною твариною» ...а й технологічною істотою. По-друге, це поняття вказує на майбутню можливість самоформування 3 допомогою форм виховання розуму, модифікування хімічних 
структур i, можливо, навіть за допомогою генетичних імпульсів» [4].

Створення «розумних» речей необхідно призводить до змін антропотехносфери, яка є частиною природи людини, частиною їі неорганічного тіла. В такому випадку людина для інженерії стає матеріалом, який досліджують, а потім перетворюють у більш досконалий. Біологічні органи людини, які мають вади, замінюють на протези; когнітивні, інтелектуальні та комунікаційні функції посилюють такими «розумними» речами, як пошукова система «гугл», телескоп «Хаббл», марсохід, смартфон, обчислювальна техніка; соціальні інститути вдосконалюються Інтернетом інфраструктури, «розумними» містами, Інтернетом послуг та продуктів тощо. Людина стає продуктом створеної антропотехнічної інженерії, вона знаходить в самій собі як творця, так і створюване. Питання полягає в розмежуванні змін, які зробив творець, і змін, які зробила створена творцем техніка. Якщо втручання здійснюється самою людиною, то вона може на власний розсуд керувати та дозувати зміни, але техніка не має людського розуму, тим більше - моральних імперативів. «Розумним» речам не властива воля, але, по-перше, закладені в них алгоритми дають можливість діяти автономно, по-друге, існує тенденція до подальшого зменшення ролі людини в інженеpiï. Можна припустити, що інженером в XXI ст. поряд з людиною стане IPP. Проблема полягає не в тому, хто перетворює природу людини, а в тому, що іiї перетворює.

Створене інженерією «розумних» речей середовище, площа його контакту $з$ людиною має колосальне соціально-антропологічне значення. Сучасна антропотехносфера «агресивно» вторгається в праксис та поезис людини і в багатьох напрямах детермінуює власного користувача. Концепт «інженерія» в сучасному світі має багато модусів, більшість 3 яких відходить від техніцистських інтерпретацій. Інженерія «розумних» речей включає в себе багато інженерій та формує соціотехнічну систему IPP, який стає новою природою-длялюдини, антропотехносферою. Автономність і аутопоетичність інженерії «розумних» речей дають змогу перебирати у людини багато ролей в процесі виробництва, що призводить до проблеми втрати «влади» над навколишнім середовищем існування. Людина в багатьох сферах сама стає продуктом інженерії «розумних» речей. Інженерія «розумних» речей, в деяких випадках 3 повноваженнями суверенного інженера, перетворює, трансформує антропотехносферу - в підсумку людина переносить трансформації власної природи. 


\section{ЛІТЕРАТУРА}

1. Gartner Says the Internet of Things Installed Base Will Grow to 26 Billion Units By 2020 [Електронний ресурс]. - Режим доступу:

http://www.gartner.com/newsroom/id/2636073

2. Центр гуманитарных технологий. Технонаука. Андрей Андреев. 25.03.2013 [Електронний ресурс]. - Режим доступу: http:/gtmarket.ru/laboratory/expertize/5993

3. Центр гуманитарных технологий. Антропотехника. 26.06.2015 [Електронний ресурс]. - Режим доступу: http://gtmarket.ru/concepts/7219

4. Философ - возмутитель умов - утверждает, что человек и машина станут единым целым. Интервью с философом Петером Слотердайком [Електронний ресурс]. - Режим доступу: http://gefter.ru/archive/16682

Омельченко Ю.О. Інженерія «розумних» речей.

В статті експлікується концепт «інженерія», розглядається його фундаментальне тлумачення. Сучасні модуси поняття «інженерія» виходять за технічно-інструменталістське коло тлумачень. Інженерія - це когнітивноперетворювальна практика. Дослідження ставить наголос на тому, що інженер XXI ст. змінює вектор своїх інтенцій з природи на саму людину. Інженерія «розумних» речей $\epsilon$ частиною соціальної інженерії. Сучасні технології, які необхідно входять в інженерію «розумних речей, мають величезне соціально-антропологічне значення. Створена інженерією XXI ст. антропотехносфера $\epsilon$ «розумним» середовищем. Ця природа-для-людини за багатьма напрямками детермінує поведінку людини. Людина зіштовхується з проблемою аутопоезису сучасної техніки, яка, в певних аспектах, може сама себе відтворювати і функціонувати поза втручанням людини. Частина, яку займає техніка в процесах трансформації природи людини, має тенденцію збільшуватися. Інженерія «розумних» речей розглядається як інженерія природи людини.

Ключові слова: інженерія, інженерія «розумних» речей, Інтернет «розумних» речей, антропотехніка, антропотехносфера.

\section{Омельченко Ю.О. Инженерия «умных» вещей.}

В статье эксплицируется концепт «инженерия», рассматривается его фундаментальное понимание. Современные модусы понятия «инженерия» выходят за границы техническо-инструменталистского круга трактовок. Инженерия - это когнитивно-преобразовательная практика. Исследование подчеркивает, что инженер XXI в. переводит вектор своих интенций с природы на самого человека. Инженерия «умных» вещей является частью социальной инженерии. Современные технологии, которые необходимо входят в инженерию «умных вещей, имеют важнейшее 
социально-антропологическое значение. Созданная инженерией XXI в. антропотехносфера является «умной» средой. Эта природа-для-человека по многим направлениям детерминирует поведение своих пользователей. Человек сталкивается с проблемой аутопоэзиса современной техники, которая, в определенных аспектах, может сама себя воспроизводить и функционировать без вмешательства человека. Часть, которую занимает техника в процессах трансформации природы человека, имеет тенденцию увеличиваться. Инженерия «умных» вещей рассматривается как инженерия природы человека.

Ключевые слова: инженерия, инженерия «умных» вещей, Интернет «умных» вещей, антропотехника, антропотехносфера.

\section{Omelchenko Y.O. Engineering of smart things.}

The article explicates the concept of «engineering» and its fundamental understanding. Modern modes of the concept of «engineering» are outside the range of technically-instrumentalist interpretations. Engineering is a cognitivetransforming practice. Research puts emphasis on the fact that the engineer of the XXI century changes the vector of its intentions with nature on the human being. Engineering of «smart» things is a part of social engineering. Modern technologies which are included in the engineering of «smart» things have enormous social and anthropological value. Build by the XXI century engineering antropotechnosphere is a «smart» environment. This nature-for-human in many ways determines the behavior of its users. Man faces the challenge of autopoiesis of modern technology which, in certain aspects, can reproduce itself and operates without human intervention. The part that takes technology in the transformation of human nature tends to increase. Engineering of «smart» things is considered as an engineering of human nature.

Key words: engineering, «smart» things, Internet of «smart» things, anthropotechnology, antropotechnosphere. 